\author{
Alexander Stoeger \\ ORCID 0000-0003-3687-5928 \\ Universiteit Leiden (Leiden, The Netherlands) \\ a.m.stoger@hum.leidenuniv.nl
}

\title{
Constructing the persona of the Naturwissenschaftler- German book reviews on galvanism
}

\begin{abstract}
Scientific book reviews were an important genre in late- $18^{\text {th }}$ century German journals. The mostly anonymous reviewers regarded themselves as voices of the scientific community, judging the quality of new publications for its benefit.

However, as this paper shows, some reviewers aspired to more than judging the books' content. The reviewers of Christian Heinrich Pfaff's, Alexander von Humboldt's, and Johann Wilhelm Ritter's monographs on galvanism, published between 1796 and 1805, used the language of epistemic virtues and vices to present their readership with their ideal scientific persona meant to support the development of the empirical sciences.
\end{abstract}

Keywords: galvanism, book reviews, language of epistemic virtue and vice, German lands, natural sciences

\begin{tabular}{|c|c|c|c|c|c|}
\hline \multicolumn{2}{|c|}{$\begin{array}{l}\text { PUBLICATION } \\
\text { INFO }\end{array}$} & Trientiarum & $\begin{array}{r}\text { e-ISSN 2543-702X } \\
\text { ISSN 2451-3202 }\end{array}$ & 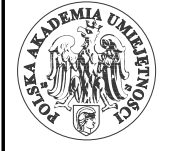 & $\begin{array}{c}\mathbf{6} \\
\text { DIAMOND } \\
\text { OPEN ACCESS }\end{array}$ \\
\hline \multicolumn{6}{|c|}{$\begin{array}{l}\text { CITATION } \\
\text { Stoeger, Alexander 2021: Constructing the persona of the Naturwissenschaftler - German book reviews } \\
\text { on Galvanism. Studia Historiae Scientiarum 20, pp. } 681-709 . \text { DOI: } 10.4467 / 2543702 X S H S .21 .020 .14051\end{array}$} \\
\hline \multicolumn{3}{|c|}{$\begin{array}{l}\text { RECEIVED: } 30.10 .2020 \\
\text { ACCEPTED: } 13.07 .2021 \\
\text { PUBLISHED ONLINE: } 13.09 .2021\end{array}$} & $\begin{array}{l}\text { ARCHIVE } \\
\text { POLICY } \\
\text { Green SHERPA/ } \\
\text { RoMEO Colour }\end{array}$ & (c) & $\begin{array}{l}\text { Similarity Check } \\
\text { Powered by iThenticate }\end{array}$ \\
\hline WWW & \multicolumn{5}{|c|}{ https://ojs.ejournals.eu/SHS/; http://pau.krakow.pl/Studia-Historiae-Scientiarum/archiwum } \\
\hline
\end{tabular}




\title{
Konstruowanie osobowości przyrodnika - niemieckie recenzje książek na temat galwanizmu
}

\begin{abstract}
Abstrakt
Ważnym gatunkiem w czasopismach niemieckich z końca XVIII wieku były recenzje książek naukowych. W większości anonimowi recenzenci uważali się za głosy środowiska naukowego, oceniając na jego rzecz jakość nowych publikacji.

Jednak, jak pokazuje ten artykuł, niektórzy recenzenci dążyli do czegoś więcej niż tylko oceniania treści książek. Recenzenci monografii o galwanizmie Christiana Heinricha Pfaffa, Alexandra von Humboldta i Johanna Wilhelma Rittera, opublikowanych w latach 1796-1805, posługiwali się językiem epistemicznych cnót i wad, aby przedstawić swoim czytelnikom idealną osobowość przyrodnika, mającą wspierać rozwój empiryczny nauki.
\end{abstract}

Słowa kluczowe: galwanizm, recenzje ksiażek, jezylk epistemicznych cnót $i$ wad, landy niemieckie, nauki prayrodnicze

\section{Introduction}

With the "communication turn", periodicals have gained new interest from historians of sciences. The genre "provides a device for situating ideas in their historical context", as Broman puts it. ${ }^{1}$ Seen not only as a medium to communicate discoveries and theories but also as crucial in forming scientific communities and disciplines, learned journals are an essential source to understand the development of the natural sciences and the ideal of the scientist. ${ }^{2}$ As has been shown in the past

1 Broman 1991, p. 13.

2 Dawson, Topham 2020, p. 6. Nyhart summarizes several different aspects of scientific journals and their function within research fields (Nyhart 1991). Although the term "natural philosopher" is commonly used for the late $18^{\text {th }}$ century, the German Naturforscher and Naturwissenschaftler as well as the term Naturwissenschaften were already well established at that time, albeit not as narrowly defined as they are today, while Naturphilosophie was a certain part of philosophy and as such rejected by many scientists (on the development of the Naturwissenschaften in Germany around 1800, see Phillips 
two decades, from the late $17^{\text {th }}$ century on, learned journals changed the scientific culture and development of research methods significantly. ${ }^{3}$ One important reason for this is that journals bore much more than just reports of discoveries, mirroring the structure of the scientific community and its development in comments, editorials, and reviews. ${ }^{4}$

In the German lands, where scholarly communication was firmly based on publications due to the dispersed intellectual centers located in many small states all over the Holy Roman Empire, periodicals thrived during the $18^{\text {th }}$ century and reviews were a successful part of them. ${ }^{5}$ Not only did they enable exchange but also helped to establish an ideal of the "new" natural scientist who used empirical methods to gain knowledge within the scientific community. ${ }^{6}$

However, while the role of the editor, the aspect of gate-keeping, the complex process of peer review, and even how journals challenged socio-cultural structures have gained much attention within the history of sciences and knowledge, scientific book reviews are still comparably unregarded, although they have been a part of scholarly exchange since the first scholarly journals emerged. ${ }^{7}$ Reviews not only served to summarize the content of books and other publications but also judged their quality and reflected on their subject and methodology. As such,

2012, especially 2-4). In this paper, the boundary work of the reviewers to Naturphilosophie plays an important part. I, therefore, use the English translation "natural scientist" or just "scientist", referring to the empirical sciences to distinguish between them. I also choose this term to emphasize the experimental aspect of the scholars' work in comparison to the often-broader used term of Naturforscher.

${ }^{3}$ Daston 1999, pp. 26-27. On the research on journals, see, for example, Csiszar 2018; and especially Britain Dawson; Lightman; Shuttleworth; Topham 2020. German journals have less often been subject of larger publications, though several studies focus on the influence of the scholarly journal on the natural sciences, for example Christoph Meinel's work on the development of chemistry (Meinel 1997), or the recently published volume edited by Katrin Löffler about Gelehrte Journale in the $18^{\text {th }}$-century German lands (Löffler 2020).

${ }^{4}$ For a deeper insight into the organization of periodicals and how they mirrored the socio-cultural structures within the scientific community, see Fyfe 2015; also Fyfe, Moxham 2016, pp. 361-379; Gielas 2020, pp. 1-16. On the role of scientific periodicals in the nineteenth century, see Csiszar 2018.

${ }^{5}$ Löffler 2020, p. 12.

6 Stoeger 2020a.

7 Jaumann 1995. 
they are a valuable source to understand the development of research disciplines and scientific values.

This paper gives an example of how scholars used book reviews to construct an image of the ideal experimental scientist based on epistemic virtues. Epistemic virtues and vices are character traits seen as having a positive or negative influence on the "efficacy in securing knowledge", often "internalized and enforced by appeal to ethical values". ${ }^{8}$ A conscientious and diligent researcher would be expected to repeat his experiments to validate his results, while his humility would help him estimating the boundaries of gaining knowledge through the conducted experiment and avoiding speculation. ${ }^{9}$ Epistemic virtues and vices mirror the scientific cultures in which they are cultivated. While other studies on the development research disciplines and the scientific self-focus on institutional or socio-cultural aspects, analyzing the role of epistemic virtues and vices within scientific debates provides a more value-based perspective. ${ }^{10}$ It also enables us to focus on important factors such as journals and research publications as a part of transinstitutional scientific debates. ${ }^{11}$ Furthermore, when lacking institutional guidelines, the rhetorical use of epistemic virtues and vices allowed scholars to communicate ideals and define a scientific identity. In the $18^{\text {th }}$ - and $19^{\text {th }}$-century scholarly discourses, epistemic virtue and vice language was often used to appeal "to norms of scientific conduct", occasionally more literal than metaphorical. ${ }^{12}$ The study of epistemic virtue and vice language helps to comprehend the structure of scientific cultures based on the self-understanding of their protagonists. This perspective is especially important when regarding the development of the German natural sciences at the end of the $18^{\text {th }}$ century when neither schools nor institutional professionalization were established enough to characterize the scientific landscape. ${ }^{13}$

${ }^{8}$ Daston, Galison 2007, pp. 40-41.

9 Kidd 2016, p. 14.

${ }^{10}$ Stichweh 1982, Clark 2006.

11 Daston, Galison 2007, p. 40. Van Dongen and Paul point out the connection between epistemic virtues and vices and the "cultural turn", understanding knowledge production through virtues and vices "as a cultural activity" (see Van Dongen, Paul 2017, p. 3). Also see Shapin 2010.

12 Van Dongen, Paul 2017, 2; Daston, Galison 2007, p. 39.

13 Breidbach, Ziche 2001, pp. 8-26. 
Regarding the use of epistemic virtue and vice language in scientific book reviews about 1800 leads us a step further, by understanding the role the genre of book reviews played in the development of a scientific persona. By evaluating a scientist's work, reviews asked for the discussion of epistemic virtues and vices. Furthermore, as this paper will show, some reviewers considered it as their duty to influence their readership through their judgment and shape a scientific persona. The case of early German research on galvanism, a new electrical phenomenon, offers an exceptional opportunity to compare reviewers' rhetorical use of the language of epistemic virtue and vice. During the 1790s, the phenomenon became a popular research topic as well as an opportunity to discuss epistemic virtues and vices. ${ }^{14}$ Numerous young researchers published the results of their experiments, eager to demonstrate their epistemic virtues to the scientific community. Christian Heinrich Pfaff (1773-1852), Alexander von Humboldt (1769-1859), and Johann Wilhelm Ritter (1776-1810) excessively used epistemic virtue language in their books on galvanism to persuade the scientific community of their capability as Naturwissenschaftler. Their reviewers picked up those efforts and re-interpreted the described virtues and vices to construct their ideal of a scientific persona. ${ }^{15}$ Regarding the reviews of three books on the same topic and with the same aims allows us to focus on epistemic virtue and vice rhetoric. It shows how the image of the authors as scientists was based on the ascribed virtues rather than the other way round.

The paper pays special attention to the rhetorical methods the reviewers used. It, therefore, does not claim to be an extensive study on scientific reviews in general, nor to encompass the situation of the natural sciences in the German lands in its entirety. The case study is limited to the reviews of the books on galvanism published in the 1790s as a consistent corpus allowing for a detailed comparison. Well-established members of the scientific community, as well as young scholars from different research fields such as physics, chemistry, and physiology, participated in the debate on galvanism, which makes it a suitable case to add to the understanding of the process of "science in the making"16 about 1800 and those who made it - amongst them the reviewers.

\footnotetext{
14 Stoeger 2021, pp. 127-129.

15 Paul 2014, p. 354.

16 Breidbach, Ziche 2001, p. 21.
} 


\section{The German natural sciences around $\mathbf{1 8 0 0}$ and the task of book reviews}

At the end of the $18^{\text {th }}$ century, the German scientific landscape changed rapidly. The debates on epistemic virtues and vices in the increasingly important scholarly journals reflected this. The beginning of professionalization and differentiation in physics, chemistry, and physiology was accompanied by debates on proper scientific methods and efforts to separate the empirical sciences from natural philosophy. ${ }^{17}$ Newly founded scientific journals played a major role in those debates. Many editors aimed to strengthen their research fields by providing an opportunity to publish discoveries and discuss research results and theories. ${ }^{18}$ Within a few decades, the scientific journal became an important medium for scholars, or, as Ritter put it in 1806: "The sciences have been cast in journals, and in those, they nearly solely live. $[\ldots]$ The truth is, to actively keep in touch with our sciences step by step, as they are right now, it is indispensable to consider the journals which contain them". ${ }^{19}$ If scholars wanted to be recognized by the scientific community, they had to contribute to journals such as the Journal der Physik [Journal of Physics], the Chemische Annalen [Chemical Annals] or the Archiv für die Physiologie [Archive for Physiology], and inevitably bend to the editors' demands.

The editors, who often were university professors, regarded themselves as managers of science, whose duty was to strengthen what they understood to be the right epistemic virtues to uphold the values of the natural sciences. ${ }^{20}$ Many editors claimed to have an educational duty in the spirit of the Enlightenment and aimed to support promising contributors who shared their ideals. ${ }^{21}$ Some based the purpose of their journals explicitly on the intention to act against the epistemic vices

17 Since these research fields had barely developed into distinct disciplines yet, I apply the categories of "physicist", "chemist", and "physiologist" to the scholars in this paper, based on their positions at university or their research interests at that time in a descriptive manner (see also Kipnis 1987). On the development of German scientific disciplines, see Stichweh 1982.

18 Broman 1991, pp. 19-20.

19 Ritter 1806, pp. XIII-XIV.

${ }^{20}$ Stoeger 2020a.

${ }^{21}$ Weiß 2008, p. 126. 
of speculation, popularization, and the pursuit for glory, which in their eyes corrupted the development of the empirical sciences, or to restrict the influence of philosophical ideas opposing experiment and observation. The editor of the Journal der Physik, Friedrich Albrecht Carl Gren (1760-1798), declared in the introduction of the periodical's first volume somewhat cautiously that he did not want to follow "the only too numerous journals" which published scientific news "only to entertain and as a mere reading amusement". ${ }^{22}$ The anonymous editors of the Journal der Erfindungen, Theorien und Widersprüche in der Natur- und Araneywissenschaft [Journal of Inventions, Theories, and Discrepancies in the Natural and Medical Sciences], calling themselves "friends of truth and frankness" described in much more detail the grievances they wanted to defeat through their journal. In the lengthy introduction to the first issue, they criticized, amongst other things, the greed for glory, causing scholars to copy their colleagues' work, ${ }^{23}$ the "arts of a Marktschreier [market crier] too frequently deceiving" ${ }^{24}$ the readership, and the speculation of young researchers "usually defending most keenly the theory [...] relying most confidently on the method that they had last heard or read of ". ${ }^{25}$ They complained about the decreasing integrity the natural sciences experienced through these vices, not only caused by researchers but also by other editors: "We could as well add that true frankness, impartiality and diligence are just not the virtues most of our critical papers can be proud of". ${ }^{26}$

The editors promoted the persona of the empirical scientist, who used experiments and observations to gain knowledge on the principles of nature. They criticized speculation, the pursuit for glory, and other epistemic vices corrupting this ideal while, at the same time, using their possibilities to support scientists who followed it. Not only editors used their position to strengthen their ideals, though. Their reviewers often followed their lead.

22 Gren 1790, p. 3.

${ }^{23}$ N.N. 1793, p. 12.

${ }^{24}$ Ibid., p. 15.

25 Ibid., p. 17.

${ }^{26}$ Ibid., p. 22. 


\subsection{Review journals and learned periodicals}

Book reviews were an established genre of the German Enlightenment, providing an opportunity to keep informed despite the increasing number of publications, and connecting authors, readership, and the scientific community through their comments. Traditionally, reviews were part of the complex stream of information in the German lands, not only summarizing books but also representing the scientific community in general. ${ }^{27}$ As such, reviews were an essential part of most scholarly journals decades before periodicals of specific research fields had been established. ${ }^{28}$ Based on the summary of the content of more extensive publications such as books, lexica, anthologies, or other journals, reviews became texts of evaluation, adding to the reviewed work as well as to the research field in general. ${ }^{29}$

Many German periodicals specialized in book reviews. The term "learned" (Gelehrte) was often part of their title, indicating the focus on scholarly topics as well as the aim to inform and teach (unterrichten in the double meaning of "inform" as well as "teach") their audience. ${ }^{30}$ Although most of those learned journals were not specializing on the topics of natural history, experimental sciences, or medicine, they nevertheless often included reviews of such publications addressed to a readership familiar with these topics. Some of them ambitiously aimed to review every newly published book. The Allgemeine Literatur Zeitung [General Literature Newspaper] (ALZ), launched in 1785 in Jena, promised its readers to discuss "all books and writings, [...] small writings, pamphlets and new maps" as well as "all foreign literature [...] interesting to Germans, not judged by other journals but by reviewers who have them on hand". ${ }^{31}$

Other journals specialized in scientific topics, for example, the Göttingische Gelehrte Anzeigen [Göttingen Learned Notifications] (GGA), founded in 1739. Alongside news about lectures and speeches held at

27 Gierl 2013, pp. 325-326.

${ }^{28}$ For the development of reviews and review journals in the 18th-century German lands, see Habel 2007; also Görmar 2020.

${ }^{29}$ Pabst 2004, 29. On the reviews of lexica, see Müller 2020.

${ }^{30}$ Löffler 2020.

31 Bertuch, Schütz, Wieland 1785, pp. 2-3. All italics in this article are from the original sources. 
the University of Göttingen, the periodical informed about discoveries and experiments of scholars from all over Europe. The information was ordered by regions and distance to Göttingen, thus representing the city as a center for research and learning. ${ }^{32}$ Other review journals applied a similar division between local and international exchange such as the Medizinisch-Chirurgische Zeitung [Medical Surgical Newspaper] (MCZ) in Salzburg, which addressed practitioners as well as researchfocused physicians. ${ }^{33}$ The reviews should evaluate the quality of medical publications and help to prevent readers from following the ill advice of charlatans and speculators. ${ }^{34}$

Commenting on the quality of publications and connecting them to current debates, reviews were a well-established genre. Meant not only to inform but also to evaluate the discussed publications and eventually guide the readership, they supported certain epistemic virtues and helped to shape the opinion of the scientific community.

\subsection{The demanding task of the reviewer}

Reviewers acted as quality control, defending acknowledged scientific methods and values against "barbarism and charlatanism". ${ }^{35}$ Discussing scientific publications was a demanding task since reviewers not only had to judge the books' content but also the experiments described and therefore needed profound knowledge of the research topic. Some reviewers went as far as reproducing the most important experiments to check the described results.

Some scholars regularly wrote reviews for specific journals using them as an established form of participating in scientific debates. The "Großrezensent" [grand reviewer] Albrecht von Haller (1708-1777) published between 1745 and 1777 as many as 9,000 reviews often instrumentalizing them to support his views. ${ }^{36}$ The reviewers of the GGA mostly consisted of professors at the University of Göttingen who were expected to contribute to the journal representing Göttingen

32 Gierl 2013, p. 327.

33 Weiß 2008, pp. 123-126.

34 Ibid., 134.

35 Ibid., 123.

${ }^{36}$ Gantet 2020, pp. 45-46 and 53-55. 
as an intellectual center. ${ }^{37}$ Other journals' reviewers contributed more infrequently.

Apart from receiving a free copy of the book, reviewers were often paid for their work, which made the task especially attractive to young scholars. Pfaff, who contributed to several journals at the beginning of his career, told his brother that he earned about 40 Florins "through reviews". ${ }^{38}$ By 1790 , the daily-appearing ALZ, which paid exceedingly well, employed 319 reviewers according to its editors. ${ }^{39}$ The weekly MCZ, focusing on medical and peripheral publications, had between 45 and 50 regular reviewers. ${ }^{40}$ Journals not entirely based on reviews frequently asked suitable candidates to apply. Finding an appropriate reviewer was often a challenge, however. Editors set a high value on the reviews' quality and declined those not meeting their expectations, even when written by well-known scholars. ${ }^{41}$ Like authors, reviewers needed certain epistemic virtues to fulfill their task adequately. The review of another scientist's work required "dignified scholars who evaluate with knowledge of the subject as well as competent judges". ${ }^{42}$ Even the reviews of general journals like the ALZ or the Reichsanzeiger addressed specialist readership familiar with the discussed topic who expected the evaluation to add to the scientific debate. Therefore, some journals refrained from employing "young, prospective scholars" who had not yet "legitimized themselves through proof of their competence to raise their voice publicly about foreign writings". ${ }^{43}$

Reviewers were expected to evaluate a researcher's contribution to a scientific debate, which not only consisted of his publication but also of his experiments. To fulfill this task, they had to be part of the scientific community and, ideally, were experienced in the topic they discussed. Reviewing was a form of taking part in scientific debates not only by evaluating colleagues' writings but also by judging their epistemic character.

\footnotetext{
37 Fambach 1976; Gierl 2013, p. 324.

38 Pfaff 1853, p. 156.

39 Pabst 2004, p. 23.

${ }^{40}$ Weiß 2008, p. 126.

${ }^{41}$ Ibid.

${ }^{42}$ Bertuch, Schütz, Wieland 1785, p. 1.

${ }^{43}$ Ibid.
} 


\subsection{The anonymous reviewer's authority - a voice of the scientific community}

An essential aspect of the reviewers' role as a judge of other scholars' work was their anonymity. While British reviewers often stayed anonymous to protect their reputation, German reviewers' anonymity was supposed to enhance their authority and allow them to pass their opinion frankly. ${ }^{44}$ Traditionally, reviewers' names were not revealed, because the reviewers were understood to represent not their personal views but the scientific community's interests. Of course, this ideal was often at odds with reality, as cases of misconduct show us. Some reviewers used their position to attack opponents or praise their own work..$^{45}$ Therefore, the principle of anonymous reviews was a regular subject of discussion amongst scholars. ${ }^{46}$

However, many long-established periodicals retained the custom, while newly founded scientific journals adopted it. Editors refrained from naming their reviewers even under hostile threat by the government or politically influential people. ${ }^{47}$ They also aimed to protect their reviewers from the wrath of authors who took their review less auspiciously. Feeling to be wrongly judged, some scholars sought the confrontation to the extent of legal actions or - in rarer cases - violence..$^{48}$ In 1753 , the secretary of the GGA vented his feelings about an author who, not satisfied with the review of his book, attacked another scholar in Göttingen whom he mistakenly assumed to be his unfavorable reviewer. ${ }^{49}$ The editor reprimanded his readership: "I hope $[\ldots]$ that those whose writings are mentioned and judged will comply my very fair

${ }^{44}$ Csiszar 2018, p. 48. The idea of the anonymous reviewer became an increasingly discussed topic in intellectual periodicals at the beginning of the $19^{\text {th }}$ century, hinting to a new understanding of the public and the relationship between the critic, the author and the readership (Pabst 2004, pp. 52-54). However, several journals, such as the MCZ and the ALZ, generally maintained the principle of the anonymous reviewer until their end in 1839 and 1864.

${ }^{45}$ Gierl 2013, pp. 332-333.

46 Pabst 2004, p. 25; Habel 2005, pp. 55-56.

47 Pabst 2004, p. 26.

${ }^{48}$ Not every objection was unwanted, though. Public conflicts were also used to gain new readers. On the policy of public disputes and polemics in review journals, see Napierala 2004, 77-112; also Denissenko 2004.

49 Michaelis 1753, pp. V-VI. 
request and to some extent the request of all other co-workers; that is, not to withdraw their sympathy and friendship if the judgement of their script might not be to their satisfaction". ${ }^{50}$

Though challenging, sustaining the reviewer's integrity not as a scholarly colleague but as an unbiased judge was critical. ${ }^{51}$ They should act as representatives of the scientific community, passing a general judgment, not an individual's opinion. To illustrate this ideal, the editors of the ALZ quoted Lessing, the highest authority of late- $18^{\text {th }}$-century German critical literature: "The reviewer not naming himself just wants to be a voice from the audience". ${ }^{2}$ He received a mandate from the scientific community to evaluate and in the case of the experimental sciences also to control another scholar's work on their behalf to add to the debates and improve the understanding of nature through scientific methods.

The reviewers regarded themselves as representatives of the scientific community, whose task was to judge the quality of the research, as well as the epistemic character traits of the researcher to guide their readership. The reviewer of the MCZ wrote about their work:

When writings which, at best, blind through new words, $[\ldots]$ through nothing more but empty hypotheses, vague ideas put in extended, rambling phrases, when, at the moment, such writings are cheered at with unparalleled approval, and their authors gain acclaim otherwise due only to the great fathers of medicine, then it is arguably the duty of the reviewer, who has to communicate with the public opinion, in particular, within the realm of science, to raise his voice..$^{53}$

Many reviewers picked up their editors' criticism against speculation and other epistemic vices damaging the natural sciences. Commenting on an author's virtues and vices as a fundament for his way to conduct his research was therefore often part of the review. Character traits

${ }^{50}$ Ibid., p. IV.

${ }^{51}$ For the scholarly persona of the judge, see Engberts 2016.

52 Lessing 1990, p. 577. Also quoted in Bertuch, Schütz, Wieland 1785, p. 2. See Pabst 2004, p. 26.

53 N.N. 1797, p. 337. 
like diligence, originality or the pursuit for glory could determine whether a publication was beneficial for the community, even if the described results would not last longer than the next set of experiments. ${ }^{54}$ If a scholar gained his research results through virtues supporting empirical methods, his work was suited as a base for further investigation, and he contributed to the empirical sciences in general. Pointing out those virtues to their readership to strengthen a scientific persona and improve research practices was part of the task of the reviewer who acted as the voice of the scientific community.

\section{Galvanism - a new phenomenon}

In 1791, the Italian anatomy professor Luigi Galvani (1737-1798) published his research on the discovery of a phenomenon he called animal electricity, soon also known as galvanism. Offering a different perspective on pressing questions in physics, chemistry, and physiology and succeeding the prevalent research on electricity, it quickly became one of the most popular research topics in Europe. ${ }^{55}$ The phenomenon was especially popular amongst German scholars, who published their research results in numerous books and journals. Many of them not only described their experiments but also discussed the epistemic virtues and vices defining the persona of the scientist based on their research. ${ }^{56}$ The phenomenon provided an opportunity to argue for appropriate scientific methods and criticize the epistemic vices threatening these methods. Some went so far as to call galvanism a chance to "save the name and honor of the current" sciences, "being of such importance and causing such high hopes that every thinking man has to and does partake in it". ${ }^{57}$ The new phenomenon could only be explored through

54 This was especially the case in the quickly progressing debate on galvanism (Trumpler 1990, p. 66). On the connection between credibility and experiment, see Shapin, Schaffer 2011, especially Ch. 2; and Franklin 1989.

55 The debates on galvanism have been subject of numerous studies. Kipnis and Bresadola give a good overview in their papers (Kipnis 1987; Bresadola 2008). On the popularity of electricity as research topic and source of entertainment, see Hochadel 2003.

${ }^{56}$ On the development of the German debates on galvanism and the role of epistemic virtues, see Stoeger 2021.

57 N.N. 1801 , p. 321. 
experiments and combined physical, chemical, and physiological aspects, which made it a suited subject to demonstrate the achievements of the empirical sciences. One scholar described galvanism as a "seed of our age" which would give rise "to a trunk whose branches, nevertheless, embrace the whole of nature". ${ }^{58}$ Another regarded the scientists researching galvanism as saviors in that age of speculation. ${ }^{59}$

The prospect of making progress quickly and the prestige of the subject made it especially attractive for young scholars who sought the recognition of the scientific community. Most publications on galvanism were written by scientists under 30 , often as inaugural dissertations. ${ }^{60}$ The young experimenters Pfaff, Humboldt, and Ritter described their epistemic virtues in their books on galvanism to meet their teachers' expectations and gain the approval of established scholars. Pfaff's Über thierische Elektricität [On Animal Electricity] (1795), Humboldt's two volumes Versuche über die gereizte Muskel- und Nervenfaser [Experiments on Stimulated Muscle and Nerve Fibres] (1797 and 1798) and Ritter's Beweis, daß ein beständiger Galvanismus den Lebensproceß in dem Thierreich begleite (Proof that Constant Galvanism Accompanies the Life Process in the Animal Kingdom] (1798) received much attention by colleagues and reviewers. ${ }^{61}$ However, while many scholars used their results as an initial point to conduct further experiments on galvanism, the numerous reviews focused on the epistemic virtues the authors promoted and re-interpreted them to present the ideal experimental scientist to their readership.

\section{The construction of a scientific persona}

Reviewers aimed to persuade their readers of their ideal scientific persona using rhetorical strategies based on epistemic virtue and vice language supported by the genre's characteristics. The topic's popularity and the young scholars' monographs provided a suitable base for the reviewers' intentions. The reviewers adopted the authors' efforts to introduce their qualities and generalized them to construct a role model

\footnotetext{
58 N.N. 1805, p. 401.

59 N.N. 1801, p. 321.

${ }^{60}$ Trumpler 1990 , p. 39.

61 On epistemic virtue language within the monographs, see Stoeger 2021, Ch. 2.
} 
against the alleged deterioration of scientific values. They consolidated their argument by describing a situation of opposites: the anonymous group of vicious speculators and charlatans standing against the exemplary young researchers representing the ideal empirical scientist.

Most of the reviews of Paff's, Humboldt's, and Ritter's books were anonymous, though we know some of the authors' names. ${ }^{62}$ Not all followed the strategy we will find in the following sections. Some of the reviews only commented on the books' content without discussing epistemic virtues or making a strong argument for a specific scientific persona. Especially the early reviews of Über thierische Elektricität were less often subjected to meta-discussion. However, in most reviews, the construction of a scientific persona was a significant aspect.

\subsection{Epistemic vices: Declaring the enemy}

Several reviewers strengthened their argument by describing an increase in epistemic vices threatening the integrity and ideals of the empirical sciences. They criticized not only those who introduced those vices but also those who allowed them to be cultivated. As the voice of the scientific community, the reviewers regarded it as their task to act against the "misuse of speculative philosophy". ${ }^{63}$ Generalizing the problems caused by epistemically vicious behavior, they pictured the deterioration of empirical methods and argued for the necessity to change.

Although galvanism did not face the same admiration as static electricity during the $18^{\text {th }}$ century regarding popularization, public presentations, and participation of laypeople in thrilling experiments, Galvani's bold statements on the connection of life and animal electricity, as well as some physiologists' optimistic speculations, called for caution amongst researchers. ${ }^{64}$ Additionally, the experiments of Franz Anton Mesmer (1734-1815) and his supporters on so-called animal magnetism in Paris during the 1780s clouded the research on anything connecting electricity and life forces. ${ }^{65}$ The popularization of electrical experiments and the instrumentalization of galvanic principles by charlatans

\footnotetext{
62 The names of the reviewers, if known, are added in the footnotes.

${ }_{63}$ N.N. 1801, p. 321.

${ }^{64}$ Hochadel 2003, Ch. 5; Stoeger 2021, p. 137.

${ }^{65}$ On the popularization of mesmerism, see Darnton 1968.
} 
influenced the reception of galvanism, especially in France and Great Britain. ${ }^{66}$ However, German reviewers identified other enemies much closer to home: philosophical speculators and glory-seekers from within the scientific community.

We can find the most drastic description in the introduction to a cumulative review titled History of the Galvanic Discovery, where the reviewer claimed: "Our age in Germany endures the impertinent hubris" of speculators and those who tried to impress others "with their wimpy opinions often enwrapped in a Schulgeschwätz [dogmatic chatter] so orotund they themselves cannot understand it and take it for the only possible knowledge", pretending "their poor quibbling for important discoveries, their denial and neglection of sophisticated knowledge to be the height of human wisdom". ${ }^{67}$ Those fraudsters would mislead other scientists, while speculators, often referred to as Theoristen [theorists], would lack the necessary humility to distinguish between evidence-based facts and hypotheses. ${ }^{68}$ This was often closely connected to the demand that the natural sciences should not be incorporated into philosophical systems, as Friedrich Wilhelm Joseph Schelling (1775-1854) tried to do. Philosophy's "empty hypotheses" followed by "the opinion of new theorists", reviewers argued, corrupted empirical research methods. ${ }^{69}$

Generalizing the epistemic vices and their negative influence was an established rhetorical strategy within the reviews to emphasize the necessity to support the right epistemic virtues. Although the reviewers described the problems they saw, they refrained from naming concrete cases. This was supposed to prevent not only objections but also strengthen the argument. The reviewers referred to issues concerning the entire scientific community. Readers could then add examples from their own experiences to confirm the reviewers' claims. ${ }^{70}$

However, reviewers criticized not only speculators and gloryseekers but also those who encouraged them and allowed the vices to thrive. ${ }^{71}$ For the reviewers, the "Nachbeter [ignorant followers] of several

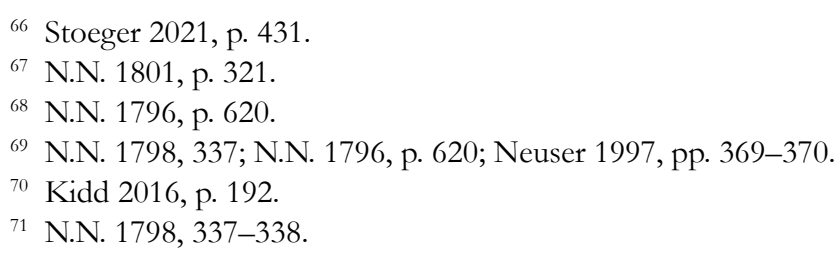


sage philosophers"72 supporting their dogmatic phrases damaged the natural sciences much more than the philosophers' writings. "[T]he abuses of speculative philosophy in the natural sciences and especially in medicine are confusing many a bright head, and a much larger number of dimmer heads is detracted from the possibility ever to come close to the truth", the reviewer of the ALZ complained. Future generations "will wonder at the indolence with which our age in Germany indulges the impertinent presumptuousness". ${ }^{73}$ Allowing the vices to thrive corrupted the natural sciences, the reviewers argued. Scholars might follow these false leads in their research as well as in their epistemic behavior. The reviewers connected the vices of some scholars to the development of the natural sciences in general, defining the future of research through epistemic behavior.

As the voice of the scientific community, reviewers were also able to guide it. Their idealized status of amorphic judges supported the impression of general disapproval in the name of the scientific community. They were assigned to criticize in the interest of science and every "thinking human". ${ }^{74}$ The collective vice-charging and the exaggerated description of the perils of misconduct emphasized the necessity of change. ${ }^{75}$ First, the reviewers described the problem; then, they presented their solution in the form of ideal role models their readership should follow.

\section{2 "Humility, a rare talent for experimenting, a spirit of observation and acuteness" - the ideal scientist}

On the one hand, the reviewers generalized the epistemic vices to illustrate a negative situation concerning every member of the scientific community. On the other hand, they depicted the books' authors as concrete examples of the ideal empirical scholar. The reviewers declared Pfaff's, Humboldt's, and Ritter's scientific success to be the result of their epistemic virtues. These character traits did not only enable them to discover new facts about galvanism but would also eventually

${ }^{72}$ N.N. 1801, p. 321.

73 Ibid.

${ }^{74}$ Ibid.

75 Kidd 2016, p. 184. 
enable young scholars to understand the laws of nature. The reviewers described the authors as opposed to the bad influence of epistemic vices and demanded their readership to follow them.

The reviewers often directly hinted at the authors' epistemic virtues, usually linking them to an aspect of the book or the whole monograph to demonstrate their positive impact and necessity. After praising Humboldt's virtues inducing the reviewer of the MCZ to "counting him amongst the first living physiologists", he explains: "The evidence for this judgment is provided by the work at hand in great quantities". ${ }^{76}$ Pfaff's "impartiality" became apparent, the reviewer of the ALZ explained, in his analysis of his colleagues' work, which he did not evaluate "without having checked the reasons [...] most diligently and accurately". ${ }^{77}$ Another characterized Humboldt's virtues:

The attentive reader will either find a new, unexpected comment or a new aspect $[\ldots]$ on nearly every page; he will often have the opportunity to admire the accuracy with which the author conducted his experiments, the tenacity with which he continued, and the acuteness with which he understood to connect and draw conclusions from them. ${ }^{78}$

A reviewer of the MCZ praised Ritter's "humility, a rare talent for experimenting, a spirit of observation and acuteness" which became apparent when reading the Beweis. ${ }^{79}$ The reviewers connected their task to discuss the monographs with their goal to present positive epistemic behavior as part of a scientific persona. They did not define their virtues, nor did they examine the authors' representation of their virtues but described them through examples of scientific success. They used the books' content as a conglomeration of examples supporting their argument and illustrating the benefits of the virtues to their readers. Although the reviewers referred to the research results described in the books as the proof of the authors' success, the actual results only played a minor role. Pfaff, Humboldt, and Ritter were not praised because

${ }^{76}$ N.N. 1798 , pp. 338-339.

77 N.N. 1796, p. 620.

${ }_{78}$ N.N. 1797 b, p. 3158.

${ }^{79}$ N.N. 1799 a, p. 273. 
they discovered a particular fact that would change the understanding of galvanism, but because their epistemic virtues enabled them to gain scientific knowledge in general.

Some of the reviewers' descriptions exaggerated the authors' achievements by using religious vocabulary, while others employed the popular topos of light and darkness to point out the authors' virtues. ${ }^{80}$ Humboldt would elucidate the "phenomena of the organic nature which until then had been enfolded in impenetrable darkness". ${ }^{81}$ The oftenused metaphor of ignorance and knowledge as darkness and light raised the ideal value of the young scholar's work; Humboldt allegorically became a figure of the Enlightenment. Another reviewer called Ritter a "chosen disciple of nature" whose "spirit" was key to accomplishing the "clearness and evidence through strict induction and careful analogy" to eventually "enter das Innere der Natur [the inner circle of Nature]". ${ }^{82}$ This metaphor of the exploration of nature as a spiritual act rather than a series of experiments changed the focus from the scientist's action to his character, strengthening the suggestion that his epistemic virtues were more important than his research results.

Although the reviewers praised the authors as the salvation of the natural sciences, they also followed their task to address issues they disapproved of, on the one hand, to follow their task of amelioration further, and on the other, not to lose credibility. However, even in their criticism, the reviewers tended to excuse the authors' flaws by holding exaggerated virtues responsible for their mistakes instead of vices. Ritter's hard to understand writing style was justified with his eagerness to "lead his reader step by step through all countless stages" of his research. ${ }^{83}$ His tiresome descriptions were not a sign of wordiness, the reviewer argued, but of overenthusiastic diligence, which might have resulted in some inconvenience for the reader, but was - strictly speaking - a virtue.

The reviewers also used attenuating descriptions to mitigate the significance of the authors' shortfalls. For example, while his arguments

${ }^{80}$ On the topos of light and darkness during the Enlightenment, see Reichard, 95-148; also Daston, Galison 2007, p. 40.

81 N.N. 1798 , p. 338.

82 N.N. 1805 , p. 401.

83 N.N. 1799 a, p. 288. 
against the anonymous miscreants and their supporters were rigorous, the reviewer of the MCZ only mildly complained about Humboldt's ignorance of another colleague's experiments. The young scholar had "rarely considered" them, and although mentioned, the reviewer did not draw any conclusions about Humboldt's virtues or vices from this point ${ }^{84}$ Controversial topics such as Ritter's search for a theory of everything were either left out or only referred to as bad habits "which should find some constraints" ${ }^{85}$ Although Ritter's assumptions could arguably be seen as speculation (and had been by other scholars), the reviewer only mildly objected. ${ }^{86}$ The reviewers turned the authors' imperfections into another example of their epistemic virtues. This kind of non-criticism through criticizing strengthened their argument and helped maintain their image of a scientific persona. The ideal they constructed did not aim for a flawless scientist but one with the right kind of flaws.

\subsection{Building disciplines - authors' virtues creating a new epoch}

The reviewers did not aim to praise Pfaff, Humboldt, and Ritter for their own sake but to provide an ideal scientific persona. Their readership should support establishing empirical research methods further. Therefore, the authors were not just described as outstanding scientists but as the response to the epistemic vices threatening the empirical sciences. Unlike some, the reviewers argued, they conducted their research "without letting [themselves] being blinded by the reputation of famous men". ${ }^{87}$

The authors' books should be regarded as guidelines for other researchers on:

circumspection with which such experiments have to be proceeded, tireless diligence with which they have to be repeated, humility with which the conclusions have to be drawn from the first experiments. One can learn these from

\footnotetext{
${ }^{84}$ N.N. 1805 , p. 354.

85 N.N. 1799 a, p. 274.

86 Wetzels 1973, pp. VII-VIII.

${ }^{87}$ N.N. 1798 , p. 346.
} 
the worthy naturalist himself; he again presents adequate evidence of them in this second volume. ${ }^{88}$

The reviewers used the young scholars' achievements from their research on galvanism as an example to be followed by all natural scientists. The scholars' virtues would save "the honor of the present science" threatened by epistemic vices and further strengthen the empirical sciences. ${ }^{89}$ Christoph Wilhelm Hufeland (1762-1836) described Humboldt as the "first physicist and scholar of nature", whose book "belongs to the classical works which make a new epoch within the sciences in general" ${ }^{\prime \prime 0}$ and in physiology in particular. The reviewer of the MCZ articulated his "true pleasure to present the audience with the detailed discussion of a work which will forever make a new epoch within the general physiology of the organic nature". ${ }^{91}$ He declared Humboldt's work to "broaden the borders of several sciences, and add especially to the founding of physiology as a science". ${ }^{92}$ The Versuche are "a work of which our nation may be proud, as it should be of its author". ${ }^{93}$ Ritter's monograph, too, would "make a new curious epoch within the newest literature of physics". ${ }^{94}$ His epistemic virtues put him in a row with the most important scholars of nature: "As Newton could have become the Gesetzgeber [appointer] of the optics only through his accuracy and diligence, so Volta and Ritter have become the equivalent for galvanism through the same accuracy as well as persevering patience in following the subject". ${ }^{5}$ The reviewer positioned the authors within a scholarly tradition of empirical methods. ${ }^{96}$ They were not only crucial for the development of certain research fields but also for the development of the German natural sciences compared to those of other nations. Their "broad, thorough knowledge, philosophical

${ }^{88}$ N.N. 1799 b, p. 149.

89 N.N. 1801 , p. 321.

${ }^{90}$ Hufeland 1797, p. 370.

91 N.N. 1798 , p. 337.

92 Ibid., p. 338.

${ }^{3}$ Ibid.

${ }^{94}$ N.N. 1805, p. 401.

95 Ibid., p. 403.

96 On Newton as a „scientific icon" and "the invention of a scientific tradition", see Higgitt 2007, p. 2. 
mind, true observational genius [...], [and] indefatigable alacrity" should be a role model for every German scientist. ${ }^{97}$ Furthermore, their services to the scientific community would not only be valued by the reviewers but also by future generations of scientists following their lead, since the authors" epistemic virtues enabled them to make "many an important discovery which will bring [them] a glorious place within the history of the sciences". ${ }^{98}$

This argument was especially strong amongst the physiologists who wanted to establish their research field as an independent discipline. ${ }^{99}$ For the reviewer of the MCZ, Humboldt's books became an example of what this new form of scientific physiology should look like, while the author "expands the boundaries of several sciences and adds to the foundation of physiology as science" ${ }^{100}$ Hufeland remarked that the Versuche "would surely have a major impact on the development and direction" of the research field. ${ }^{101}$ The reviewers described the connection between the authors' accomplishments and the development of the natural sciences often at the beginning and the end of their reviews to frame the summary of the author's work.

The reviewers exaggerated the importance of the authors and their books to the scientific community to install them as role models. Pfaff, Humboldt, and Ritter became models of the persona of the empirical scientist. The reviewers' descriptions idealized the young authors and their work to provide an example for their readership. The reviewers did not discuss books on galvanism, but guidelines of epistemic behavior to shape the present and future of the natural sciences.

\section{Conclusion}

At the turn of the $18^{\text {th }}$ century, book reviews still played a crucial part in German scientific debates. By evaluating the content and credibility of a monograph, as well as its importance for the research debate, they

${ }_{97}$ N.N. 1798 , p. 338.

98 N.N. 1805 , p. 403.

${ }^{99}$ Broman 1991, p. 22. On the professionalization of physiology and medicine in Germany around 1800, see also Broman 1996.

100 N.N. 1798 , p. 338.

101 Hufeland 1797, p. 370. 
helped to connect the vast number of publications and supported the communication network of the scientific community. Many reviewers, however, regarded their task to reach further than just commenting on other scholars' research. They understood themselves to be assigned by the scientific community to judge their colleagues' work and maintain the ideals of the empirical sciences.

Though limited to a small but extraordinarily active research debate, this study gave an example of how reviewers used the language of epistemic virtues and vices to introduce a specific scientific persona representing the ideal empirical scientist. It offered a new perspective on the debates about the scientific self around 1800 amongst German scholars. Broadening this perspective with reviews on other publications on galvanism and comparing it with the ideals of philosophers of nature in future studies will shed a different light on the complex interdependence between German Naturwissenschaft and Naturphilosophie.

The character of the text genre of book reviews, still underestimated within the communication turn, makes it an essential source to understand the development of scientific disciplines and epistemic values. This case study illustrated how the language of epistemic virtues and vices was used to influence the development of the natural sciences. Providing the guidelines for scientific research on epistemic virtues and vices enabled consistency within a plurality of organizational structures, different traditions and research perspectives characterizing German natural sciences at the end of the century. As different perspectives on a particular genre, they are snapshots of knowledge production and epistemic self-understanding, and add layers of information and context to the books they discuss. As such, the genre of book reviews deserves more attention as a source for the development of scientific values and research disciplines.

\section{Bibliography}

\section{ACRONYMS}

Allgemeine Literatur Zeitung = ALZ

Medicinisch-Cbirurgische Zeitung = MCZ

Göttingische gelebrte Anzeigen, Göttingische Anzeigen von gelahrten Sachen = GGA 


\section{SOURCES}

Bertuch, Friedrich Justin; Schütz, Christoph G. \& Wieland, Christoph Martin 1785: Vorbericht. ALZ 1(1), pp. 1-3.

Gren, Friedrich Albrecht Carl 1790: Vorrede. Journal der Physik. 1(1), pp. 2-7.

Hufeland, Christoph Wilhelm 1797: Review on Humboldt's Versuche über die gereizte Muskel- und Nervenfaser. Journal der practischen Aræneykunde und Wundarzneykunst 4(1). pp. 370-371.

Lessing, Gotthold Ephraim 1990: „Briefe antiquarischen Inhalts.“ [In:] Werke und Briefe in zwölf Bänden, Vol. 5/2. Edited by Wilfried Barner. Frankfurt a. M.: Suhrkamp. ISBN: 978-3-618-61180-6, pp. 577.

Michaelis, Johann David 1753: Vorrede. GGA 1, pp. I-XIV.

N.N. 1793: Vorrede. Journal der Erfindungen, Theorien und Widersprüche 1(1), pp. 12.

N.N. 1796: Review of Pfaff's Über thierische Elektricität. ALZ 2(182), pp. 620-624.

N.N. 1797a: Review of Humboldt's Versuche über die gereizte Muskel- und Nervenfaser Vol. 1. MCZ 4(98-100), pp. 337-347.

N.N. 1797b: Review of Humboldt's Versuche über die gereizte Muskel- und Nervenfaser Vol. 1. Kaiserlich Privilegierter Reichsanzeiger 2, pp. 3157-3159.

N.N. 1798: Review on Humboldt's Versuche über die gereizte Muskel- und Nervenfaser Vol. 1. Neue Allgemeine Deutsche Bibliothek 68(2), pp. 343-357.

N.N. 1799a: Review of Ritter's Beweis, daß ein beständiger Galvanismus. MCZ 2(41), pp. 273-288.

N.N. 1799b: Review on Humboldt's Versuche über die gereizte Muskel- und Nervenfaser Vol. 2. MCZ 3(148), pp. 148-163.

N.N. 1801: Geschichte der Galvanischen Entdeckung. ALZ Ergänzungsblätter 119-123, pp. 321-436.

N.N. 1805: Review of Ritter's Beweis, daß ein beständiger Galvanismus. ALZ 4(310), pp. 401-406.

Pfaff, Christoph Heinrich 1853: Letter to his brother Johann Friedrich Pfaff - Rome, April 20 1796. [n:] Sammlung von Briefen gewechselt zwischen Johann Friedrich Pfaff und Herzog Carl von Würtemberg, F. Bouterwek, A. v. Humboldt, A. G. Kästner, und Anderen. Edited by Christian Heinrich Pfaff. Leipzig: Hinrichs'sche Buchhandlung, pp. 150-158.

Ritter, Johann Wilhelm 1806: Vorerinnerung. Physisch-chemische Abhandlungen in chronologischer Folge 1(1). Leipzig: Reclam, pp. XIII-XIV. 


\section{STUDIES}

Breidbach, Olaf; Ziche, Paul 2001: Einführung. Naturwissen und Naturwissenschaften - Zur Wissenschaftskultur in Weimar/Jena. [In:] Naturwissenschaften um 1800. Wissenschaftskultur in Jena/Weimar. Edited by Olaf Breidbach and Paul Ziche. Weimar: Verlag Hermann Böhlhaus Nachfolger. ISBN 978-3-74001177-2, pp. 8-26. https://doi.org/10.1007/978-3-476-02828-0.

Broman, Thomas H. 1996: The transformation of German academic medicine 1750-1820. Cambridge: Cambridge University Press. ISBN 0-521-55231-1.

Broman, Thomas H. 1991: J. C. Reil and the ,Journalization' of Physiology. [n:] The Literary Structure of Scientific Argument. Edited by Peter Dear. Philadelphia: University of Pennsylvania Press. ISBN 0-81220-8185-3, pp. 13-42.

Cantor, Geoffrey; Shuttleworth, Sally 2004: Science Serialised. Representation of the Sciences in Nineteenth-Century Periodicals. Cambridge: Cambridge University Press. ISBN 978-0-262-03318-3.

Clark, William 2006: Academic Charisma and the Origins of the Research University. Chicago and London: University of Chicago Press. ISBN 0-226-10921-6.

Csiszar, Alex 2018: The Scientific Journal. Chicago: The University of Chicago Press. ISBN 978-0-226-55337-5. https://doi.org/10.7208/chicago/978022 $\underline{6553375.001 .0001 .}$

Darnton, Robert 1968: Mesmerism and the End of the Enlightenment in France. Cambridge, Massachusetts, and London: Harvard University Press. ISBN 0-67456951-2.

Daston, Lorraine; Galison, Peter 2007: Objectivity. New York: Zone Books. ISBN 978-7-890951-78-8.

Daston, Lorraine 1999: Die Kultur der wissenschaftlichen Objektivität. [In:] Naturwissenschaft, Geisteswissenschaft, Kulturwissenschaft: Einheit - Gegensatz - Komplementarität? Edited by Otto Gerhard Oexle. Göttingen: Wallstein Verlag. ISBN 3-89244-320-3, pp. 9-40.

Dawson, Gowan; Topham, John R. 2020: Introduction: Constructing Scientific Communities. [In:] Science Periodicals in Nineteenth Century Britain. Constructing Scientific Communities. Edited by Gowan Dawson, Bernard Lightman, Sally Shuttleworth, and John R. Topham. Chicago: University of Chicago Press. ISBN 978-0-226-68346-1, pp. 35-64. https://doi.org/10.7208/chicago/9780226683461.001.0001

Dawson, Gowan; Lightman, Bernard; Shuttleworth, Sally; Topham, John R. 2020: Science Periodicals in Nineteenth Century Britain. Constructing Scientific Communities. Chicago: University of Chicago Press. ISBN 978-0-226-68346-1, pp. 35-64. DOI: https://doi.org/10.7208/chicago/9780226683461.001.0001. 
Denissenko, Irina 2004: Die inszenierte Öffentlichkeit des Streites. Die Gattung Antikritik und das kritische Profil der Allgemeinen Literatur-Zeitung. [In:] Organisation der Kritik. Die Allgemeine Literatur-Zeitung in Jena 1785-1803. Edited by Stefan Matuschek. Heidelberg: Universitätsverlag Winter. ISBN 978-3-8253-1618-1, pp. 113-142.

Engberts, Christiaan 2016: The Scholar as Judge. A Contested Persona in Nineteenth-Century Orientalism. Low Countries Historical Reviews 131(4), pp. 93-111. https://doi.org/10.18352/bmgn-lchr.10266.

Fambach, O. 1976: Die Mitarbeiter der Göttingischen Gelehrten Anzeigen 17691836. Tübingen: Universitätsbibliothek.

Franklin, Allan 1989: The epistemology of Experiment. [In:] The Uses of Experiment. Studies in Natural Sciences. Edited by David Gooding, Trevor Pinch and Simon Schaffer. Princeton: Princeton University Press. ISBN 0-521-33185-4, pp. $437-460$.

Fyfe, Aileen 2015: 350 Years of Scientific Periodicals. Notes and Records 69, pp. 227239. https://doi.org/10.1098/rsnr.2015.0036

Fyfe, Aileen; Moxham, Noah 2016: Making Public ahead of Print. Meetings and Publications at the Royal Society, 1752-1892. Notes and Records 70, pp. 361-379. https://doi.org/10.1098/rsnr.2016.0030.

Gantet, Claire 2020: Der Großrezensent Albrecht von Haller. Hallers Exzerpte und Rezensionen in den Jahren 1745 bis 1747. [In:] Wissen in Bewegung. Gelehrte Journale, Debatten und der Buchhandel der Aufklärung. Edited by Katrin Löffler. Stuttgart: Franz Steiner Verlag. ISBN 978-3-515-12592-5, pp. 45-62.

Gielas, Anna 2020: Turning tradition into an instrument of research: The editorship of William Nicholson (1753-1815). Centaurus 62(1), p. 1-16. https:/ / doi.org/10.1111/1600-0498.12283.

Gierl, Martin 2013: The Gelehrte Zeitung: The Presentation of Knowledge, the Presentation of Göttingen University, and the Praxis of Self-Reviews in the Göttingische Gelehrte Anzeigen. Archives Internationales d'Histoire des Sciences, 63(170171), pp. 321-341. https://doi.org/10.1484/J.ARIHS.5.103849

Görmar, M. 2020: Die Vor- und Frühgeschichte der Acta Eruditorum im Kontext der Leipziger Sozietätslandschaft des 17. Jahrhunderts. Zum Verhältnis von journalistischer Rezensions- und sozietärer Vortragspraxis. [In:] Wissen in Bewegung. Gelehrte Journale, Debatten und der Buchhandel der Aufklärung. Stuttgart: Franz Steiner Verlag. ISBN 978-3-515-12592-5, pp. 31-44.

Habel, T. 2005: Deutschsprachige Rezensionszeitschriften der Aufklärung. Zur Geschichte und Erschließung. [In:] Historische Presse und ibre Leser. Studien zu Zeitungen und Zeitschriften, Intelligenzblättern und Kalendern in Nordwestdeutschland. 
Edited by Peter Albrecht and H. Böning. Bremen: edition lumière. ISBN 9783-934-68623-6, pp. 42-77.

Habel, Thomas 2007: Gelehrte Journale und Zeitungen der Aufklärung. Zur Entstehung, Entwicklung und Erschließung deutschsprachiger Rezensionszeitschriften des 18. Jahrbunderts. Bremen: edition lumière. ISBN 978-3-934-68628-1.

Higgitt, Rebekah 2007: Recreating Newton. Newtonian Biography and the making of Nineteenth-Century History of Science. London: Pickering \& Chatto. ISBN 9781-851-96906-7.

Hochadel, Oliver 2003: Öffentliche Wissenschaft. Elektrizität in der deutschen Aufkelärung. Göttingen: Wallstein. ISBN 3-89244-629-6.

Jaumann, H. 1995: Zur Rhetorik der Literaturkritik in der frühen Neuzeit. Colloquia Germanica 28(3-4), pp. 191-202. https://www.jstor.org/stable/23980682

Kidd, Ian James 2016: Inevitability, contingency, and epistemic humility. Studies in History and Philosophy of Science 55, pp. 12-19. https://doi.org/10.1016/j. shpsa.2015.08.006

Kipnis, Naum 1987: Luigi Galvani and the Debate on Animal Electricity, 1791-1800. Annals of Science 44, pp. 107-142. https://doi.org/10.1080/00033798700200151

Bresadola, Marco 2008: Animal Electricity at the End of the Eighteenth Century: The Many Facets of a Great Scientific Controversy. Journal of the History of Neurosciences 17, pp. 8-32. https://doi.org/10.1080/09647040600764787

Löffler, Katrin 2020: Wissen braucht einen Träger. Gelehrte Blätter als zentrales Medium der Aufklärung. [In:] Wissen in Bewegung. Gelehrte Journale, Debatten und der Buchhandel der Aufklärung. Edited by Katrin Löffler. Stuttgart: Franz Steiner Verlag. ISBN 978-3-515-12592-5, pp. 9-30.

Meinel, Christoph 1997: Fachzeitschriftentum, Bibliothek und Naturwissenschaft im 19. und 20. Jahrbundert. Wiesbaden: Harrassowitz Verlag. ISBN 978-3-447-03913-0.

Müller, Andreas 2020: Rezensionen des allgemeinen Wissens. Frühneuzeitliche Lexika im Blickfeld zeitgenössischer Rezensenten. [In:] Wissen in Bewegung. Gelehrte Journale, Debatten und der Buchhandel in der Auflelärung. Edited by Katrin Löffler. Stuttgart: Franz Steiner Verlag. ISBN 978-3-515-12592-5, pp. 109-122.

Napierala, Mark 2004: Unparteilichkeit und Polemik. Kritik am Rezensionswesen und die Ordnung der Gelehrtenrepublik. [In:] Organisation der Kritik. Die Allgemeine Literatur-Zeitung in Jena 1785-1803. Edited by Stefan Matuschek. Heidelberg: Universitätsverlag Winter. ISBN 978-3-8253-1618-1, pp. 77-112.

Neuser, Wolfgang 1997: Die Methoden der Naturwissenschaften im Spiegel der frühen Naturphilosophie Schellings. [n:] „Fessellos durch die Systeme“. Frühromantisches Naturdenken im Umfeld von Arnim, Ritter und Schelling. Edited by Walther Ch. Zimmerli, Klaus Stein and Michael Gerten. Stuttgart: frommann-holzboog. ISBN 978-3-77281833-2, pp. 369-389. 
Nyhart, Lynn K. 1991: Writing Zoologically: The Zeitschrift für wissenschaftliche Zoologie and the Zoological Community in Late Nineteenth-Century Germany. [n:] The Literary Structure of Scientific Argument. Edited by Peter Dear. Philadelphia: University of Pennsylvania Press. ISBN 0-8122-8185-3, pp. 43-45.

Pabst, Stephan 2004: Der anonyme Rezensent und das hypothetische Publikum. Zum Öffentlichkeitsverständnis der Allgemeinen Literatur-Zeitung. [In:] Organisation der Kritik. Die Allgemeine Literatur-Zeitung in Jena 1785-1803. Edited by Stefan Matuschek. Heidelberg: Universitätsverlag Winter. ISBN 978-3-8253-1618-1, pp. 23-54.

Paul, Herman 2014: What is a Scholarly Persona? Ten Thesis on Virtues, Skills, and Desires. History and Theory 53, pp. 348-371. https://doi.org/10.1111/ hith.10717

Reichard, Rolf 1998: Light against Darkness: The Visual Representations of a Central Enlightenment Concept. Representations 61, pp. 95-148. https://doi. org/10.2307/2902949

Phillips, Denise 2012: Acolytes of Nature. Defining Natural Science in Germany 17701850. Chicago: University of Chicago Press. ISBN 978-0-226-66737-9.

Shapin, Steven; Schaffer, Simon 1985: Leviathan and the Air-Pump. Hobbes, Boyle, and the Experimental Life. [ $2^{\text {nd }}$ Edition] Princeton: Princeton University Press. ISBN 978-0-691-15020-8.

Shapin, Steven 2010: Never Pure: Historical Studies of Science as if It was Produced by People with Bodies, Situated in Time, Space, Culture, and Society, and Struggling for Credibility and Authority. Baltimore: John Hopkins. ISBN 9-7-8080189421-3.

Stichweh, Rudolf 1982: Ausdifferenzierung der Wissenschaft - Eine Analyse am deutschen Beispiel. Bielefeld: B.K. Verlag. ISBN 3-88302-042-7.

Stoeger, Alexander 2020a: ,Journale sind es, in die diese Wissenschaften sich ergossen haben“ - Fachzeitschriften als Diskussionsräume naturwissenschaftlicher Forschungsmethoden um 1800. [In:] Wissen in Bewegung. Gelehrte Journale, Debatten und der Buchhandel in der Aufkelärung. Edited by Katrin Löffler. Stuttgart: Franz Steiner Verlag. ISBN 978-3-515-12592-5, pp. 231-243.

Stoeger, Alexander 2021: Epistemische Tugenden im deutschen und britischen Galvanismusdiskurs um 1800. Munich: Wilhelm Fink. ISBN 978-3-8467-6548-7.

Trumpler, Maria 1990: Questioning Nature: Experimental investigations of Animal Electricity in Germany, 1791-1810. Yale: University. [Dissertation Thesis]

Van Dongen, Jeroen; Paul, Herman 2017: Introduction: Epistemic Virtues in the Sciences and Humanities. [In:] Epistemic Virtues in the Sciences and Humanities. Edited by Jeroen van Dongen and Herman Paul. Cham: Springer. ISBN 978-3-31948892-9, pp. 1-10. https://doi.org/10.1007/978-3-319-48893-6. 


\section{History of scientific knowledge}

Weiß, Alfred Stefan 2008: Salzburger Medizin um 1800 - Der Arzt Dr. Johann Jakob Hartenkeil (1761-1808), sein Leben und Wirken in der Stadt Salzburg. Mitteilungen der Gesellschaft für Salzburger Landeskunde XX. Salzburg, Gesellschaft für Salzburger Landeskunde 148. pp. 105-146.

Wetzels, Walter D. 1973: Johann Wilhelm Ritter: Physike im Wirkungsfeld der deutschen Romantik. Berlin: Walter de Gruyter. ISBN 3-11-003815-3. 